University of Nebraska - Lincoln

DigitalCommons@University of Nebraska - Lincoln

Faculty Papers and Publications in Animal

Science

Animal Science Department

November 1963

\title{
Genotype and Variability in Dairy Lactation Records
}

L. Dale Van Vleck

University of Nebraska-Lincoln, dvan-vleck1@unl.edu

G. R. Barr

Cornell University

Follow this and additional works at: https://digitalcommons.unl.edu/animalscifacpub

Part of the Animal Sciences Commons

Van Vleck, L. Dale and Barr, G. R., "Genotype and Variability in Dairy Lactation Records" (1963). Faculty Papers and Publications in Animal Science. 170.

https://digitalcommons.unl.edu/animalscifacpub/170

This Article is brought to you for free and open access by the Animal Science Department at DigitalCommons@University of Nebraska - Lincoln. It has been accepted for inclusion in Faculty Papers and Publications in Animal Science by an authorized administrator of DigitalCommons@University of Nebraska - Lincoln. 
Published in Genetics 48: 1441-1443 (November 1963).

Copyright (c) Genetic Society of America.

Available online at:

http://www.genetics.org/cgi/reprint/48/11/1441

\title{
Genotype and Variability in Dairy Lactation Records
}

\author{
L. D. Van Vleck and G. R. Barr \\ Cornell University, Ithaca, New York
}

Submitted April 29, 1963

\begin{abstract}
In quantitative genetics, the variation of individuals within genetic groups is commonly attributed to environment. The assumption is then made that the environmental variances are similar from one group to another. Complications arise in the application of selection index theory when this assumption is not made. The results reported here indicate that in a population of dairy records, the environmental variance is not similar from one genetic group to another. Johnson (1945) and Wadell, Van Vleck and Henderson (1960) found similar results with fewer data.
\end{abstract}

